\title{
"Well Sir Thomas?": Oration to commemorate the tercentenary of the death of Sir Thomas Browne
}

\author{
FRANK LIVINGSTONE HUNTLEY
}

Now that we celebrate the three hundredth anniversary of the death of Sir Thomas Browne rather than his birth I intend to concentrate not on Browne's melancholia but on his joy, not on Hydriotaphia but on his happiest, most difficult, and most challenging piece, The Garden of Cyrus.

Of his five major works, the Religio Medici-an acknowledged masterpiece-was written by a physician not quite 30 years of age. Browne's best known book, it has inspired by its quiet faith, detachment, and charming mixture of pride and humility millions of thoughtful people around the world. The young doctor seems to delight in his often very bad poetry while being oblivious to the fact that he could write perhaps the finest prose in the English language. Take, for example, this passage on Judgment Day:

"This is the day that must make good that great attribute of God, his
Justice, that must reconcile those unanswerable doubts that torment the
wisest understandings, and reduce those seeming inequalities, and
respective distributions in this world, to an equality and recompensive
Justice in the next. This is that one day, that shall include and compre-
hend all that went before it, wherein as in the last scene, all the Actors
must enter to compleate and make up the Catastrophe of this great
peece. This is the day whose memory hath onely power to make us
honest in the darke, and to bee vertuous without a witnesse" (p 119).

He had forgotten that he could write like this until Andrew Crooke in 1642 pirated the first edition. Browne's corrected version became immediately popular in England, and its Latin translation soon gave him a continental reputation.

Now married and settled in Norwich with his expanding practice and collections of books, coins, zoological specimens, and medicinal herbs, Browne was busy working on his Pseudodoxia Epidemica, the epidemic disease of fallacious opinions, solving the problem as any doctor would, first by determining the cause and then by applying the cure. Known as "Vulgar Errors," this work was published in six editions between 1646 and 1672. A 1652 Danish translation in manuscript at the University of Copenhagen library testifies that he was early known in Europe not only as a literary man but as a scientist as well. To the new science Francis Bacon had lent a Senecan English prose style and the majestic robes of office, but Browne, with his own laboratory and training in observation, worked in the tradition of Vesalius, Aquapendente, William Harvey, and the founders of the Royal Society. He cleared the way through hundreds of popular errors by applying to them the two great determinators of truth, reason and ocular observation.

Yet superstitions are hard to stop. The Victorian Welsh vicar, the Reverend Francis Kilvert, reports this one in his Diary on 1 February 1871 . One morning Mrs Jones discovered that some articles of clothing had disappeared from the hedge where she had laid them to dry, and her suspicions fell on some of the neighbours. Mr Jones made some wet clay into a ball and inside placed a live toad and a piece of paper. The ball was then put into the fire to bake and in the process the toad was expected to scratch the name of the thief on the paper placed beside him. "It is almost incredible," added the Reverend Mr Kilvert.

Delivered at the Festival held in Norwich, 25 June 1982.

\footnotetext{
Department of English Language and Literature, University of Michigan, Ann Arbor, Michigan, USA

FRANK LIVINGSTONE HUNTLEY, professor emeritus
}

Pseudodoxia Epidemica is filled with reverent passages on death and resurrection, for, like most of the early members of the Royal Society, Browne was a Christian, secure in the view of history that though we may wander in the desert of error God has a plan for us after all, a straight line that leads from our mortality to His eternity (p 252). ${ }^{1}$ Despite many a solemn incantation, the Pseudodoxia is, again, lightened by Browne's humour. If Rome were built in a day, as the proverb goes, "that were an art lost with our mechanics." And he calls the case of a woman who insisted that she got pregnant from taking a bath "a new and unseconded way in history of fornicating at a distance."

The successive editions of Browne's scientific magnum opus were interrupted by his being called to the bedside of the literary Robert Loveday, dying of tuberculosis in the nearby village of Chediston in East Suffolk. Struck by the purity of his young patient's character, the physician was moved to write an account of the death to a friend and one-time Norwich neighbour, Sir John Pettus, who, being absent at the time, would want to know the details of his "intimate friend's" passing. Browne ends his letter with some frank advice to Sir John on how better to conduct himself as a Royalist during the interregnum and as a member of the aristocracy at a time when a revolution was going on in manners as well as in politics and religion. Instinct told Browne that his letter had literary merit, so he expanded the advice at the end into Christian Morals, a loose collection of pious maxims admired by Dr Johnson, and reworked the letter itself into a minor masterpiece. It was not published until 1690, eight years after its author had died. For a long time it was thought that this Letter to a Friend was composed near the end of Browne's life, but it is practically certain now that its 1656 lucubrations on mortality were a fitting prelude to that masterpiece on the ending of things, Hydriotaphia.

But before we consider the twin works of 1658, Hydriotaphia or Urn Burial and The Garden of Cyrus, an account of Dr Thomas Lushington, Browne's Oxford tutor, may reveal the man who perhaps had the greatest influence upon Browne as an artist and also partially explain Browne's neutral response to the political events of his time.

And first a general word about the pupil-master relationship. The greater a man is, usually the more generous in aiding those who seek to learn from him, and it is meet and right that the pupil honour his master. Young Henry Power of Halifax thanks Dr Browne for encouraging the publication of the first book on microscopy in England, but Dr Browne is strangely silent on the subject of his own teachers. If he had only mentioned, for example, the name of the country doctor who had presided over his four-year apprenticeship in medicine, we would know exactly where the Religio Medici had been written.

Thomas Lushington at Oxford had taught the youthful Thomas Browne grammar, rhetoric, and logic but became much more famous as the wittiest preacher the undergraduates had ever heard. On 28 April 1624 he preached the Easter Monday sermon at St Mary's on Matthew 28:13-"Say ye, his disciples came by night, and stole him away while we slept." Imagining the group around the empty tomb, in a sustained passage of sometimes angry dialogue among the women, a Roman soldier, several Jewish priests, and members of the rabble, he brings to life the miracle of the Resurrection. The student congregation burst into applause. But since the theatricality was shocking to some elders and two brief passages reflected upon King James's Spanish policy and the honour of Parliament, Lushington was forced on the following Sunday to preach a recantation. This pair of sermons reverberated through history for a century. 
Born and baptised in Sittingbourne, Kent, Lushington attended King's School in Canterbury and matriculated at Broadgates Hall, Oxford, when Thomas Browne was a 1-year-old infant. After taking the $\mathrm{BA}$ and MA from Lincoln, he returned to Broadgates to tutor and to continue his study of divinity. He was at Broadgates when it became Pembroke College. On this grand occasion young Thomas Browne was the only undergraduate chosen to give a speech, in Latin, no doubt coached by Lushington. The teacher proceeded to the BD and DD, by this time serving as chaplain to Bishop Corbett of Oxford.

Though Lushington wrote books on logic and the Neoplatonic mathematics of Proclus, the witty Easter Monday sermon and its recantation set his reputation for the rest of his career. Such notoriety had one blessing, however-an interest in Lushington as a preacher that preserved in the Bodleian five other sermons preached by him at Oxford; they are in various hands, probably taken down by studentlisteners. The ingenuity with which he turns apparently unpromising texts into the most surprising cases of conscience links him to his more famous contemporaries, Lancelot Andrewes and John Donne, for his sermons possess intellectual sinew. They also ring with a conversational pace that reminds one of Shakespeare's yeomen speaking English to one another: "Our Saviour bids His disciples beware of the leaven of the Pharisees, and they dream of that knapsack they had no bread in." Despite many a pun, passages of tenderness are followed by those of pith and energy; the preacher suddenly turns from pitying Mary Magdalene as she weeps before the empty tomb to a relentless analysis of her lack of faith in the Resurrection. The more he displays his gifts of mind, the weaker he knows they are. "Lord, what a wretch am I, a tamed fool, a broken-brained dunce" sounds like Hamlet. Again, "What another conceives I cannot, though upon the same evidence, and there is no great hold to what I myself conceive, for what I believed yesterday I may doubt today and tomorrow find myself quite deceived." Perhaps subconsciously echoing his college tutor, Browne expressed a similarly sceptical thought in the Religio: "I could never divide my selfe from any man upon the difference of an opinion, or be angry with his judgement for not agreeing with mee in that, from which perhaps within a few dayes I should dissent my selfe" (p 65). ${ }^{1}$

It was Lushington's wit and commonsense theology that attracted Richard Corbett of St John's to him, and through Corbett's promotions Lushington's Oxford career came to an end. An old Broadgates man himself, Corbett was famous as a witty versifier and perhaps shone most brilliantly in Lushington's company. The conviviality of these two in their cups became a legend. In Aubrey's words, "The Bishop would sometimes take the key of the wine-cellar and he and his chaplaine would lock themselves in and be merry: then first he lays down his episcopal hood, and 'There layes the doctor'; then he puts of his gowne, 'There layes the bishop'; and then 'twas, 'Here's to thee Corbet,' and, 'Here's to thee Lushington.' "' They must have been great bowlers together and in a tight spot were used to calling for the resin for their hands. During a confirmation service, Corbett came to a candidate's head at the altar rail glistening in its baldness. Laying both hands upon it, the Bishop was heard to whisper, "Some dust, Lushington!' Let us hope the new communicant received a bias toward heaven.

For better and for worse, Lushington and Corbett were Archbishop Laud men. Thanks to Laud, Corbett rose fast, from the deanery of Christ Church Cathedral to the bishopric of Oxford, and then to Salisbury. On the death of Bishop White he was translated to Norwich, accompanied by Lushington. The Archbishop, attempting to rule all Anglican England as he had once ruled Oxford, could use such high church wits as these two to help reclaim East Anglia. Corbett, during his brief régime of three years (for he died in 1637), suspended some 30 ministers for not following the prescribed ritual; and his successor, Bishop Wrenn, carried out even more drastic "measures" as England drifted inexorably towards civil war. The more Archbishop Laud and Charles I forfeited an ancient strength of Anglican ecclesiastical polity - to bend, to accommodate, to give, to persuade-the stronger grew their opposition. When in 1639 Lushington had to surrender his Norwich holdings to Presbyterians, the King presented him with the tiny benefices of Burnham-St Mary, Burnham-All Saints, Burnham-St Margaret, and Burnham-Westgate, all in the district of Hunstanton, Norfolk.

The move to oust him from this semi-retreat began, unsuspectingly, with the publication in 1646 of a book by "G M." Its title was innocent enough: The Expiation of a Sinner. In a Commentary upon the Epistle to the Hebrews. "G $\mathrm{M}$ " has never been identified. The emphasis upon Christ's post-resurrection Godhead and the interpreting of many expressions in the Epistle as metaphors that less rationally inclined theologians took as literal truths made its author suspect. Dr John
Downame, however, well known Puritan divine and Parliamentary licensor of books, had given the book his imprimatur.

Despite this official stamp, in 1655 the book was declared to be atheistic and was ascribed to Thomas Lushington by the Reverend Edmund Porter, Puritan, of the Cathedral Church in Norwich, probably still seething from the "persecutions" of the late Bishop Corbett and his still living chaplain. In the preface to his Theus Anthropophos or God Incarnate, the Reverend Mr Porter asserts that he was drawn to write his book:

by the iniquity of a most blasphemous Book lately Printed, and called A Commentary on the Hebrews, written by a nameless Doctor of Divinity, who now resideth in this Countrey, but formerly of Broadgates Hall, (so it was then called) wherein he hath vented such blasphemies against Jesus Christ, as I without special revocation and repentance, will in the end bring both himself, and all his seduced sectaries to the woeful Broad-gate of which mention is made, Matt 7:13. Lata est porta quae ducit ad perditionem."

The old joke on Broadgates Hall and the word "revocation" show that the reputation of Lushington's early pair of sermons in Oxford had followed him to East Anglia.

To assume that a man who is not far over to the right must be far over to the left is, of course, nonsense, as Sir John Suckling of Norwich was aware. When certain people did not like the religion or politics of others, they called them by a name that hisses, like "Socinian," after the founder of the anti-trinitarian sect; and they hinted at conspiracy. In his Account of Religion by Reason (1646) to the same Earl of Dorset who so quickly had recommended Religio Medici to Sir Kenelm Digby, Suckling wrote: "I send you (my Lord) that Discourse enlarged ... which had like to make me an Atheist at Court, and your Lordship no very good Christian. I am not ignorant that the fear of Socinianism at this time, renders every man that offers an account of Religion by Reason, suspected to have none at all."

One year after Porter's diatribe, The Commentary upon the Hebrews was reissued with a new title page that substituted for the author's initials, "G M," a new set of initials, "T L D D," that is "Thomas Lushington Doctor of Divinity." Thus Lushington was branded as a heretic. There is no record of his denying authorship. Who would have listened to him? Archbishop Laud had long since been executed; Parliament had published The Directory of Publique Worship, and Cromwell had abolished The Book of Common Prayer. The Presbyterian and Independent parties were in power. No one came to Lushington's defence, not even Dr Browne of Norwich.

I am convinced that Lushington did not write the suspect Commentary upon the Hebrews. The "evidence" Porter gives for his authorship consists of name-calling, raking up the ancient pair of Oxford sermons, and deliberately misinterpreting the grounds for the recantation as theological. They were political. None of the writings that are unquestionably Lushington's contain a trace of Socinian thinking, and no one thought of calling him a Socinian before Porter's unwarranted attack.

Lushington could no longer stay in Norfolk. He returned to Sittingbourne. Then in 1659 appeared the first printing of the two famous Oxford sermons, the recantation changed radically from the manuscript we possess in order to make it more incriminating. On one of the British Library's printed copies is scribbled an anonymous note dated 1662: "I have heard this sermon was ... commonly called Lushington against $\mathrm{Xt}$, for he was suspected of being a Socinian." More difficult to understand is why Dr Thomas Browne, who was of scholarly bent, without more inquiry included in his 1672 letter to Aubrey "G M's" Commentary upon the Hebrews among Lushington's publications.

Popular opinion shifted towards the Restoration of the monarchy. The surviving Anglican bishops, anticipating the re-establishment of their hierarchy, selected the Reverend John Barwick to gather their views on the preservation and take them to Charles II in the Dutch city of Breda. At this national and ecclesiastical crisis, it may be a compliment to the force and genius of Thomas Lushington that among only seven recommendations to the new king one whole recommendation, item No 5, should warn His Majesty against the 70-year-old former Oxford tutor, "... till Enquiry should be made concerning his suspected Faith and Principles." Lushington died at Sittingbourne on 22 December 1661, and there was set up in St Michaels's Church an ornate monument depicting him as a scholar.

But his unenviable reputation lived on. In 1712 Curll, as recorded by Professor Finch, published the Posthumous Works of Sir Thomas Browne. Prefixed to the volume is an anonymous "Life" largely copied from Anthony a Wood but with an important addition, the Reverend John Whitefoot's "Some Minutes for the Life of Sir 
Thomas Browne." These papers reached Curll through Elizabeth Lyttleton, Browne's only surviving child, and the Reverend White Kennett, later Bishop of Peterborough. Concerning Browne's coming to Norwich, Anthony a Wood had affirmed: "About this time he [Browne] by the persuations of Thomas Lushington his some time tutor, retired to the City of Norwich...." The anonymous "Life" follows Wood until the name of Lushington. Then, on a cancelled leaf, the respectable names of Sir Nicholas Bacon, Sir Justinian Lewyn, and Charles le Gros are substituted. When singled out by this negating notice, Lushington had been in his grave for 51 years. It is almost incredible.

His monument in Sittingbourne was ironically destroyed in 1762 by a fire, the same element that had preserved the Walsingham urns discovered not two miles from his other home in Burnham, Norfolk. On these his former student had discoursed very eloquently. Much has been written of the student. Here is a garland for the teacher. He had taught the young Thomas Browne the arts of language, and perhaps by negative example for the rest of the physician's life how to stay free of political and theological entanglement. If there is such a thing as academic guilt by association, Browne may have suffered when, for writing Religio Medici, he was called everything from atheist to Quaker to papist. I am sure that Sir Geoffrey Arthur, Master, is justly proud of Pembroke College, but in Browne's day it was a dangerous place.

While his old tutor was being driven out of Norfolk, Browne was single-mindedly composing The Garden of Cyrus. By its length and the amount of detailed research that went into it, it was surely begun well before and finished after Hydriotaphia, Browne tells us that the incinerated urns broke in upon his more serious study: "We were hinted by the occasion, not catched the opportunity to write of old things, or intrude upon the Antiquary. We are coldly drawn unto discourses of Antiquities, who have scarce time before us to comprehend new things, or make out learned Novelties" (p 264). ${ }^{1}$ Of course, Hydriotaphia is superb. What student of literature has not intoned the beginning of its last chapter? "Now since these dead bones have already out-lasted the living ones of Methuselah, and in a yard under ground, and thin walls of clay, out-worn all the strong and specious buildings above it; and quietly rested under the drums and tramplings of three conquests; What Prince can promise such diuturnity unto his Reliques, or might not gladly say, Sic ego componi versus in ossa velim ?" (p 306). ${ }^{1}$ Of the twin essays, Urn Burial will always be preferred, for it is human to feel more at home on the ground. Many a student starts to read Dante's Divine Comedy but gets no further than the Inferno. He also begins to read Milton's Paradise Lost but stops after the first two books, which are set in hell and much more exciting.

Twenty years ago I proposed that the first essay cannot be read without the second, for the two pieces are purposefully antithetical and correlative. The first is death; the second, life. The first is guess-work, the second, science. The first is accident; the second, its opposite, design. The first is sad; the second filled with garden delights. The first describes pagan customs; the second rests on Christian faith. Browne himself gives us at least two indications of their nexus and the reason for their order. One comes in his preface to Nicholas Bacon: "That we conjoyn these parts of different Subjects.... Your judgement will admit without impute of incongruity; Since the delightfull World comes after death, and Paradise succeeds the Grave" (p 321). The other is his description at the end of chapter IV of The Garden of the Greek "theta" in solid geometry from Plato's Timaeus ( $p$ 378).1 "Theta" is the first letter in thanatos (death) and in theos (God, who is Life). Take two strips of paper, Browne says, and cross them in the middle; then, bending them into two circles, make them intersect at opposite points like the meridian and equator on a geographical globe. In this "theta" made in solid geometry, the vertical circle is an emblem of the soul, eternity, God; the horizontal line of the other circle signifies body, time, mortality. Turning the globe reveals the intersection, the decussation, the cross, death and resurrection.

Beloved and great though Hydriotaphia is, I shall now argue that The Garden of Cyrus is greater. Browne's last major work, it is the climactic statement of his life's faith, in the form of prophecy. "Prophecy" used to involve Scriptural interpretation and in consequence sermonising. It also meant the prediction with exact times and places, mostly by quacks like "Arise" Evans, of future events (p 118). ${ }^{1}$ Browne rejects both these meanings. The Garden of Cyrus is prophecy in the Biblical sense. Why "Cyrus" in the title? Browne confesses that the hanging gardens may well have been begun by Nebuchadnezzar, the proud royal predecessor of Cyrus at Babylon. Then he adds laconically that Cyrus the Great so nobly beautified them "that he was also thought to be the author thereof" (p 327). ${ }^{1}$ Except for a brief denial of relevance (p 369), ${ }^{1}$ this is the last we hear of Cyrus, barely into the first three pages of the essay. Of course Browne had read his Herodotus and Xenophon, but he also knew that Cyrus is mentioned in the Bible only by the prophets, for it was Cyrus who led the children of Israel out of captivity back to Jerusalem. Read the final verses of Second Chronicles: "Now in the first year of Cyrus king of Persia, that he made a proclamation throughout all his kingdom, and put it also in writing, saying, Thus saith Cyrus king of Persia, All the kingdoms of the earth hath the Lord God of heaven given me: and he hath charged me to build him a house in Jerusalem, which is in Judah" (Ezra 6:3). Isaiah takes up the happy theme: "Thus saith the Lord to his anointed, to Cyrus ... to open before him the two-leaved gates; and the gates shall not be shut" (45:1). "[Cyrus] is my shepherd, and shall perform all my pleasure: even saying to Jerusalem, Thou shalt be built, and to the temple, Thy foundations shall be laid" $(44: 28)$. By the very choice of his title, "The Garden of Cyrus," Browne invokes the prophetic voices of the Old Testament to proclaim his own prophecy.

Prophecy in the Biblical sense is a discovery, a vision, a revelation of a profound truth that requires an act of faith. From the Old Testament it sprang again in the great prototype of St John's The Book of Revelation. The literary tradition has been carried on by Dante, by Sidney's hailing the poet once more as vates, by Spenser and Milton, and later by Blake and Shelley. In England its development was aided by the over 85 commentaries on The Book of Revelation published in the first half of the seventeenth century, particularly by the more literary explanations of David Paré, Joseph Mede, and, later, Henry More. These literary characteristics will be postponed for a moment in order to note that prophecy must have a clear statement, usually near the end, of the "truth" that has been revealed, the various details contributing to its declaration. Also, there is usually an occasion for prophesying, a need for hope out of despair. The Old Testament prophets wrote during the Babylonian captivity. The truth that John saw comes in the last chapter when Jesus says, "And, behold, I come quickly; and my reward is with me, to give to every man according as his work shall be. I am Alpha and Omega, the beginning and the end, the first and the last" (22:12-13). The occasion for John was the Roman persecution (Revelation $6: 9 ; 16: 6 ; 17: 6$ ). The vision that Browne believes and sets down at the end of The Garden is: "All things began in order, so shall they end, and so shall they begin again; according to the ordainer of order and mystical mathematics of the city of heaven" ( $p$ 387). ${ }^{1}$

Did Browne have occasion to prophesy, to hope for order out of chaos and despair? An even closer picture of the times he was writing in than that which emerged from the account of Lushington comes in the diary of John Evelyn. On 26 January 1657 Evelyn wrote a long letter to his epistolary friend, Dr Browne in Norwich, interestingly enough on the subject of gardens. "Were it to be hoped," he wrote, "... these innocent, pure and usefull diversions might enjoy the least encouragement, whilst brutish and ambitious persons seeke themselves in the ruines of our miserable yet dearest country." On 26 February 1657 Evelyn wrote in his diary: "The Protector Oliver, now affecting Kingship, is petitioned to take the Title on him by all his new-made sycophart Lords...." In August 1657 he bemoaned "the folly of a sort of enthusiasts and desperate Men, pretending to set up the kingdom of Christ with the sword. To this pass was this age arrived when we had no King in Israel." 
Evelyn described a surreptitious Anglican service in London on Christmas Day 1657. The Reverend Mr Gunning had finished his sermon on the prophet Micah 7:2- "The good man is perished out of the earth, and there is none upright among men; they hunt every man his brother with a net." During the Holy Eucharist that followed Cromwell's soldiers invaded the room and took every communicant off to prison for questioning; Evelyn was released, others detained. "A sad day! The Church now in dens and caves of the earth," wrote Evelyn (Diary, 23 March 1658).

But though Browne, as an Anglican, must have longed for the return of the ancient rites, his prophecy transcends England and the seventeenth century. It embraces God's preconceived plan for His creation, to be carried into effect no one knows when (Mark 13:32) but for the believer certainly to be carried into effect. Like many others, Browne saw indications that history was close to its end; the feeling inspired him not to political action but to Neoplatonic abstractions and Christian millenarianism. That The Garden of Cyrus is just such a millenarian prophecy may now be demonstrated more specifically by the built-in literary traits of prophetic writing illustrated by the prototype of Christian prophecy, The Book of Revelation. These traits usually overlap but in the order of their increasing impact upon the reader of Browne's essay they are: synchronism, typology, pictorialisation, numerology, and multiplicity.

Prophecy cannot escape synchronism, where one time slot slides into another with no logical transition, for example: "I am Alpha and Omega, the beginning and the end." In the Gospel according to St John, Jesus pleads with the Father "to glorify me ... with the glory I had with thee before the world was" $(17: 5)$. Browne at the age of 30 had been struck with the mixture of tenses in Christ's saying, "Before Abraham was, I am" (John 8:58), which reminded him that "Eve miscarried of mee before she conceived of Cain" (p 132). 'In The Garden of Cyrus, time moves from ancient Egyptian lore to Browne's own garden, back to Eden, forward to Moses, forward to Nebuchadnezzar, and back again to the third day of creation. Browne speculates on the existence of orchards before the Flood, then after Noah had planted vineyards, and back to Eden if God had set the Tree of Knowledge in its centre (pp 332-3). ${ }^{1}$ Presumably speaking in God's voice, the prophet shares God's knowledge that a thousand years in our eyes are but a second in His (p 252). ${ }^{1}$ For the Protestant Christian, such synchronism also rests on Augustinian psychology, wherein the three powers of the soul -memory, understanding, and will-act not sequentially as in Thomism but simultaneously.

Itself akin to synchronism, typology is a more easily recognisable ingredient of prophecy. By analogy Christians early found in the Old Testament precursors of the New. St Paul's saying, for example, that Christ is the second Adam (1 Corinthians $15: 22)$ shows how typology is inseparable from prophecy in that the type demands fulfillment in the anti-type, Adam being the type and Christ the anti-type. More than half of the verses in The Book of Revelation quote or allude to verses in the Old Testament. John starts in the present, goes back to type, and leaps forward to eschatology. So Browne in The Garden of Cyrus begins with anti-types, that is, "artificial" man-made things such as the planting of trees in the lozenge-pattern after the sixth day of Creation. These objects have their type in the world after the third day of Creation ("natural"). Then nature as a type becomes the anti-type for the original type in the mind of God ("mystical"). Browne begins with orchards, rhomboidal arches, circles, and coins because we cannot recognise a type until the anti-type is before us. All typology is ex post facto.

More easily understood than the typology in The Garden of Cyrus is the pictorialisation. In his teaching, the prophet uses visual arts, like Michael in the futuristic final two books of Paradise Lost. He makes us observe as well as hear. The Book of Revelation proceeds by pictures of sealed scrolls, angels, trumpets, dragons, and candlesticks. Prophetic poets like Dante and Milton give birth to Gustave Doré, and Blake's remarkable engravings say as much as his prophetic poems do. Browne was fond of paintings and statues and kept telling his children to be sure to learn how to "limn." He also delved into the pictorial writing of ancient Egypt, emblems, hieroglyphs, which were supposed to have been available to Moses, a prophet, from the 400 year habitation of that land by the Jews. So a sentence in The Garden can combine typology with a picture like this: “. . . he that considereth the plain crosse upon the head of the Owl in the Laterane Obelisk, or the crosse erected upon a pitcher diffusing streams of water into two basins, with sprinkling branches in them, and all described upon a two-footed Altar, as in the Hieroglyphicks of the brazen Table of Bembus; will hardly decline all thought of Christian signality in them" ( $p$ 330). ${ }^{1}$ The reader of Chapter III of The Garden, moreover, peers over Browne's shoulder into a botanist's field book containing sketches of hundreds of plants. Phrases like "It may be observed," "It is easily observable," "Therein one may see" abound on every page. In addition to five-petalled flowers we are made to look at crucigerous crowns, medals, beds, nets, perspective in drawing, cut jewels, battle formations, butterfly wings, and constellations in the sky-all presenting the central sacred decussation, the Greek "chi," the Roman X, two Roman five's (V) joined at their apices to make the perfect number ten. Such pictures, Browne would conclude, "afford those delightful Truths, confirmable by sense and ocular Observation, which seems to me the surest path, to trace the Labyrinth of Truth" (p 386). ${ }^{1}$

As obvious as the pictures in prophetic writing is the numerology. "Forty" is a favourite number in the Bible. In The Book of Revelation it is seven and three and even the number of the beast. In the Divine Comedy it is the number three, and incidentally Browne is one of the few seventeenth century Englishmen who repeatedly quotes Dante. In The Garden of Cyrus it is the litany on the number five. The piece is built on the quincunx, that is a pattern of five like the five-spot in a deck of cards, four spots at the corners and one spot in the centre. Arising from the ancient method of planting orchards, the design in a continued pattern gives the greatest amount of nutrients for the roots and of air and moisture for the branches, at the same time affording to the eye straight rows of trees from every vantage point. Browne uses numbers to discover the pattern of the universe. Plato, not Aristotle, was the mathematician, and prophecy, as with John of Patmos, flourishes in a Neoplatonic ambience; hence Browne's allusion to the Timaeus, Plato's mathematical dialogue on the Creation. By what luck or mysterium Browne wrote five great works we do not know, but he did write (1) Religio Medici, (2) Pseudodoxia Epidemica, (3) $A$ Letter to a Friend, (4) Hydriotaphia, and (5) The Garden of Cyrus. I had fun picking out five traits of prophetic writing: (1) synchronism, (2) typology, (3) pictorialisation, (4) numerology, and (5) finally...

Prophetic writing is characterised by excess, an overwhelming multiplicity as though, speaking for God, the prophet imitates the extravagance of God's creation. Excess abides in Browne's habit of saying he will omit something and then going right ahead to give it a minute description. "We shall decline the old themes," he says (p 329)1 but he does not. "We shall not call in the Hebrew Tenupha," ( $p$ 338) ${ }^{1}$ but he does. "To omit the position of the squared stones," (p 344),1 "to omit many other analogies," (p 344), ${ }^{1}$ "to omit the ancient Cornopeion" ( $p$ 336), "We shall not prie into it" (p 337)1-these are typical phrases. Despite promises to skip subjects, Browne incorporates them all as his examples burgeon. We are overwhelmed by the number of "whys ?" Why did Christ feed five thousand persons with five loaves of bread? Why did David have five pebbles in his pouch? Why did the ancients mix five parts of water with their wine? Why should only a 5-year-old ox be an acceptable sacrifice to Jupiter? Why? Why? Why? The answers are not amenable to reason; man can only wonder. But there it is laid out in a panoply intended to boggle the mind. Through his compulsion to speak the truth as he sees it, the prophet makes us surrender to the evidence. God, according to the Wisdom of Solomon, ". . ordered all things by measure, number, weight" 
(11:21); hence from the very nature of creation Browne may conclude: "All things began in order, so shall they end, and so shall they begin again; according to the ordainer of order and mystical mathematics of the City of Heaven."

Browne could not know in 1658 that he would live for another 24 years. As though The Garden of Cyrus is actually his final work he joins it, like a snake swallowing its own tail, to his first work, for in the Religio he had written:

"I beleeve the world growes neare its end, yet is neither old nor decayed, nor will ever perish upon the ruines of its own principles. As the worke of Creation was above nature, so its adversay, annihilation. ... Now what force should bee able to consume it . . . without the breath of God ... my Philosophy [meaning natural science] cannot informe mee. [The beginning and the end] ... rather seem to manifest the method and Idea of the great worke of the Intellect of God ..." (p 117).

So I end my discourse with the Norwich statue of our beloved Browne, to remind ourselves that though every physician faces death, life is his greater concern. Browne in stone contemplating the ashes of the dead is part of the romantic reading of him in 1905, stemming from Coleridge, Lamb, and De Quincy. For 77 years an awed public had gazed at Browne's skull in a glass case in the hospital museum. Literary criticism of Browne from Walter Pater, Ernest Dowson, Leslie Stephen, and Edmund Gosse pictured him as quaint, fussing around with antique trifles while sounding his melancholy organ notes. George Saintsbury even scanned the whole final chapter of Urn Burial, and included its author in a chapter entitled "Antiquaries" for The Cambridge History of English Literature.

Today, surely, we realise that Browne's brilliant mind, measured energy, and unwavering Christian faith go far beyond this. Hence, I am bold enough to prophesy that twice every century until the last syllable of recorded time, this City of Norwich will rethink and recelebrate the life, work, and death of its universal citizen.

Portions of this oral presentation receive more scholarly treatment in forthcoming publications: The Garden of Cyrus as Prophecy, in Approaches to Sir Thomas Browne: The Ann Arbor Tercentenary Lectures and Essays, ed C A Patrides (University of Missouri Press); and the Lushington material in Modern Philology (University of Chicago Press).

\section{Reference}

1 Patrides CA, ed. The major works of Sir Thomas Browne. Harmondsworth, Middlesex: Penguin Books Ltd, 1977.

\title{
Browne 300: Festival at Norwich
}

\author{
STEPHEN LOCK
}

Volume 2 of the $B M F$ for 1905 contained no fewer than 10 entries devoted to $\mathrm{Sir}$ Thomas Browne to commemorate the tercentenary of his birth. Foremost among these was an address given at Guy's Hospital by none other than Dr William Osler, then Regius Professor at Oxford, who dealt with the man and his writings, concluding that "mastery of self, conscientious devotion to duty, deep human interest in human beings-these best of all lessons you must learn now or never; and these are some of the lessons you may glean from the life and from the lips of Sir Thomas Browne." The length of Osler's address ( $5 \frac{1}{2}$ pages in small type) was almost equalled by a description of the ceremonies at Norwich: the unveiling of Pegram's statue next to St Peter Mancroft (the church where Browne worshipped and where he is buried); the Memorial Service in the same church; and a luncheon at the Blackfriars Hall.

Reading the accounts of speeches by all the assembled worthies, I was struck by how much styles have changed in three-quarters of a century. The emphasis of Browne 300last week's splendid festival held in Norwich to commemorate the tercentenary of his death-was on informality. True, there was a certain amount of necessary seriousness: an opening ceremony and a memorial service with a sermon by the Dean of St Paul's and lessons read by the Master of Pembroke College, Oxford, and the President of the Royal College of Physicians. But last week the dignitaries wore neither gowns nor top hats, and Dr Anthony Batty Shaw, the festival's energetic moving spirit, had ensured that there was street theatre, performances of Purcell's King Arthur, and an exhibition

British Medical Journal, London WC1H 9JR

STEPHEN LOCK, MA, FRCP, editor of commemorative pottery-not to mention a Tercentenary Peel rung on the bells of St Peter Mancroft, that masterpiece of a parish church with its famous roof and stained glass.

\section{Browne, Norfolk, and Norwich}

Part of Browne's appeal to us today as a man is that he quietly continued cultivating his family, his profession, and his own interests in an age that resembled our own: violent, threatening, and bewildering. Norwich, where he lived for the last 40 years of his life, was then the second largest city in England, and, though in supporting the Puritans it had been on the winning side of the Civil War, it had felt its effectsslump, unemployment, conscription, and heavy taxes. The Cathedral had been sacked by some of the townsfolk and St Peter Mancroft seriously damaged in "The Great Blow," an explosion occurring when some gunpowder had ignited in a nearby arsenal being looted by the mob. Even when Charles II had been restored to the throne, Rachel Young reminded us in the session devoted to Browne, Norfolk, and Norwich, there had been the Great Plague and subsequent near famine, averted only by a timely glut of herring at Yarmouth.

Thus violence and potential disaster had continually been in the background of Browne's life at Norwich. Nevertheless, he had also found the time to be active as a naturalist, Ted Ellis showed. In an age when Norfolk was still largely a neglected and straggling wilderness he had become the first complete naturalist, interested in everything: badgers, beetles, butterflies, fish, fungi, and seeds, to mention only a few. The first to mention in print the existence of the Norfolk Broads, by keeping a bitterne in his backyard, Browne had typically disposed of the myth that the bird produced its boring sound by putting its bill into hollow reeds, mud, or water.

Continuing this theme of scientific curiosity, Anthony Batty 